\title{
Global Threat Reduction Initiative Fuel Thermo-Physical Characterization Project Quality Assurance Plan
}

\section{Pereira} BD Slonecker

June 2012

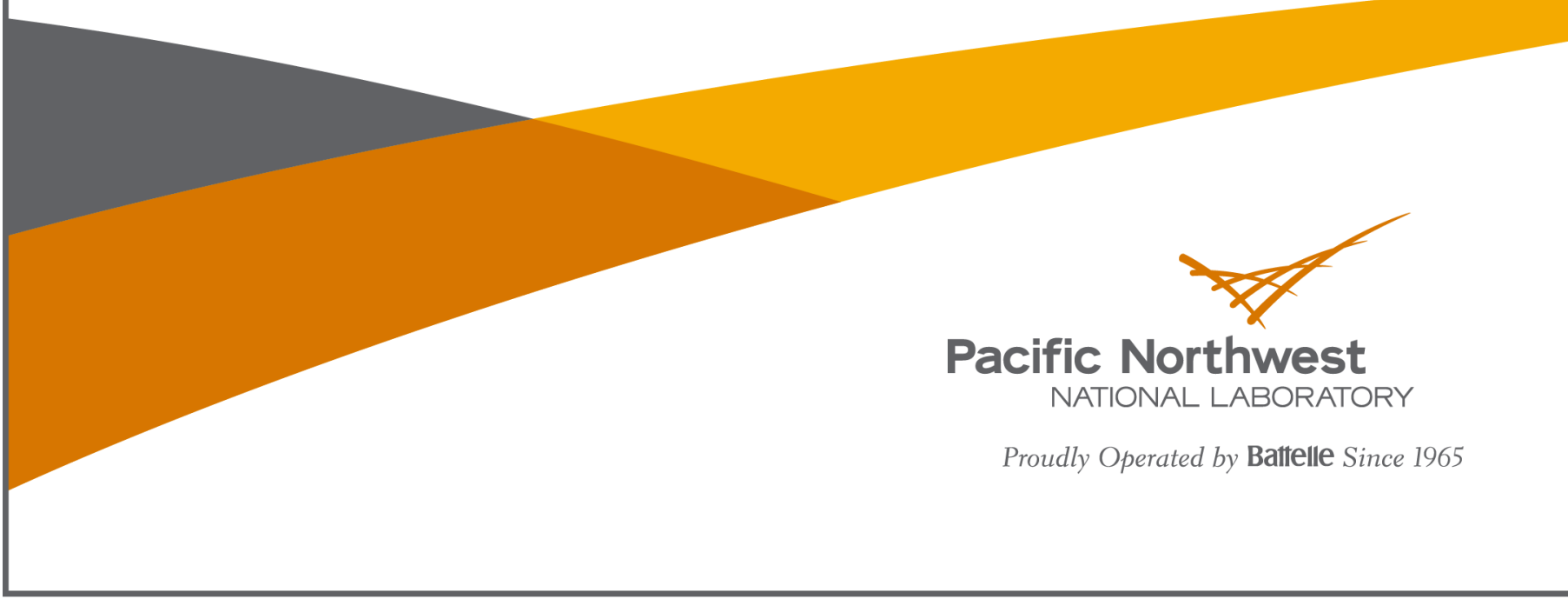




\title{
DISCLAIMER
}

This report was prepared as an account of work sponsored by an agency of the United States Government. Neither the United States Government nor any agency thereof, nor Battelle Memorial Institute, nor any of their employees, makes any warranty, express or implied, or assumes any legal liability or responsibility for the accuracy, completeness, or usefulness of any information, apparatus, product, or process disclosed, or represents that its use would not infringe privately owned rights. Reference herein to any specific commercial product, process, or service by trade name, trademark, manufacturer, or otherwise does not necessarily constitute or imply its endorsement, recommendation, or favoring by the United States Government or any agency thereof, or Battelle Memorial Institute. The views and opinions of authors expressed herein do not necessarily state or reflect those of the United States Government or any agency thereof.

\author{
PACIFIC NORTHWEST NATIONAL LABORATORY \\ operated by \\ BATTELLE \\ for the \\ UNITED STATES DEPARTMENT OF ENERGY \\ under Contract DE-AC05-76RL01830 \\ Printed in the United States of America \\ Available to DOE and DOE contractors from the \\ Office of Scientific and Technical Information, \\ P.O. Box 62, Oak Ridge, TN 37831-0062; \\ ph: (865) 576-8401 \\ fax: $(865) 576-5728$ \\ email: reports@adonis.osti.gov \\ Available to the public from the National Technical Information Service \\ 5301 Shawnee Rd., Alexandria, VA 22312 \\ ph: (800) 553-NTIS (6847) \\ email: orders@ntis.gov <http://www.ntis.gov/about/form.aspx> \\ Online ordering: http://www.ntis.gov
}

This document was printed on recycled paper.

(8/2010) 


\section{Global Threat Reduction Initiative Fuel Thermo-Physical Characterization Project Quality Assurance Plan}

M Pereira

BD Slonecker

June 2012

Prepared for

the U.S. Department of Energy

under Contract DE-AC05-76RL01830

Pacific Northwest National Laboratory

Richland, Washington 99352 



\section{Revision Log and Approvals}

\begin{tabular}{|c|c|c|c|c|}
\hline \multicolumn{5}{|c|}{ Quality Assurance Plan Revision History } \\
\hline Rev. No. & Comments/Changes & Revision Date & Date & Approvals \\
\hline 0 & Initial document issued & Revision 0 & June 2012 & ERICA Release PNNL-21531 \\
\hline & & & & \\
\hline & & & & \\
\hline
\end{tabular}

\begin{tabular}{|l|l|l|}
\hline Name and Title & Approvals & Date \\
\hline $\begin{array}{l}\text { MM Pereira, } \\
\text { Project Manager }\end{array}$ & ERICA Release PNNL-21531 & July 9, 2012 \\
\hline $\begin{array}{l}\text { WJ Martin } \\
\text { Program Management Office Director }\end{array}$ & ERICA Release PNNL-21531 & July 9, 2012 \\
\hline $\begin{array}{l}\text { BD Slonecker } \\
\text { Quality Engineer }\end{array}$ & ERICA Release PNNL-21531 9012 \\
\hline & & \\
\hline & & \\
\hline
\end{tabular}

Note: Document approvals that were received via email are retained in the project records. 



\section{Executive Summary}

The charter of the Fuel Thermo-Physical Characterization Project is to ready Pacific Northwest National Laboratory (PNNL) facilities and processes for the receipt of unirradiated and irradiated low enriched uranium (LEU) molybdenum (U-Mo) fuel element samples, and to perform analysis to support the Global Threat Reduction Initiative conversion program. PNNL's support for the program will include the establishment of post-irradiation examination processes, including thermo-physical properties, unique to the U.S. Department of Energy laboratories. These processes will ultimately support the submission of the base fuel qualification (BFQ) to the U.S. Nuclear Regulatory Commission (NRC) and revisions to High Performance Research Reactor Safety Analysis Reports to enable conversion from highly enriched uranium to LEU fuel.

This quality assurance plan (QAP) provides the quality assurance requirements and processes that support the NRC BFQ. This QAP is designed to be used by project staff, and prescribes the required management control elements that are to be met and how they are implemented. Additional controls are captured in Fuel Thermo-Physical Characterization Project plans, existing procedures, and procedures to be developed that provide supplemental information on how work is conducted on the project. 



\section{Acronyms and Abbreviations}

GTRI

HDI

HEU

ITS

LEU

LRB

M\&TE

NQA

PEP

PMP

PNNL

QA

QAP

$\mathrm{QC}$

RPL
Global Threat Reduction Initiative

How Do I?

highly enriched uranium

Issue Tracking Tool

low enriched uranium

laboratory record book

measuring and test equipment

Nuclear Quality Assurance

project execution plan

project management plan

Pacific Northwest National Laboratory

quality assurance

Quality Assurance Plan

quality control

Radiochemical Processing Laboratory 



\section{Contents}

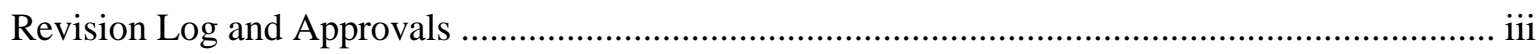

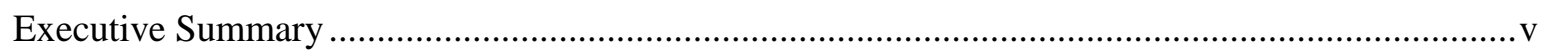

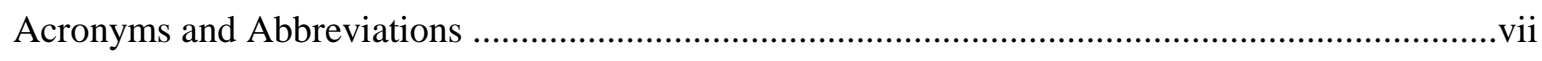

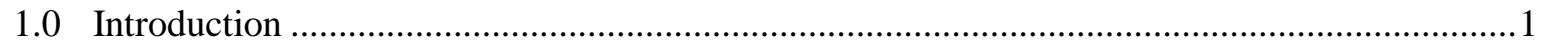

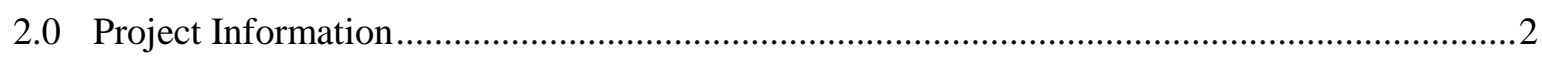

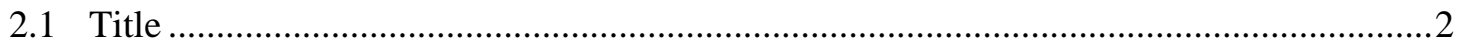

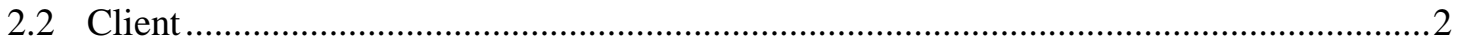

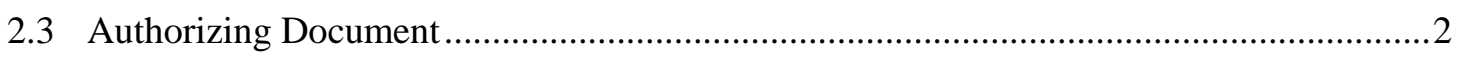

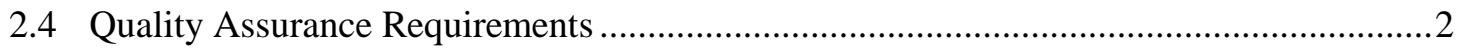

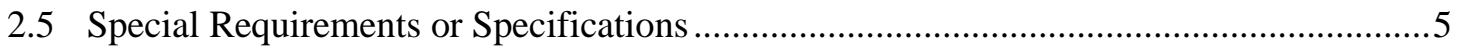

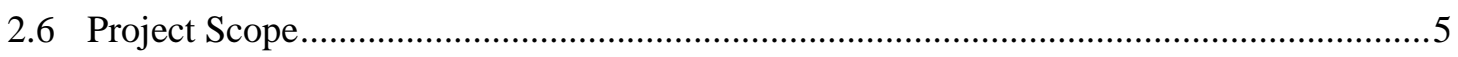

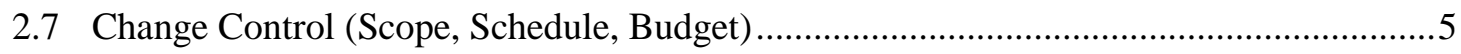

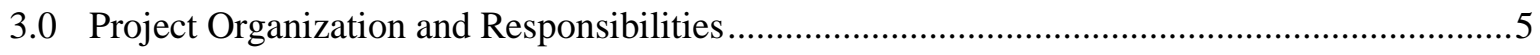

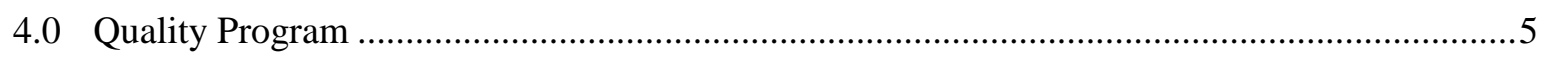

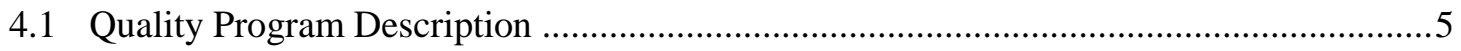

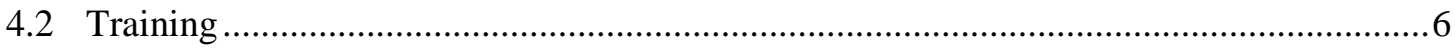

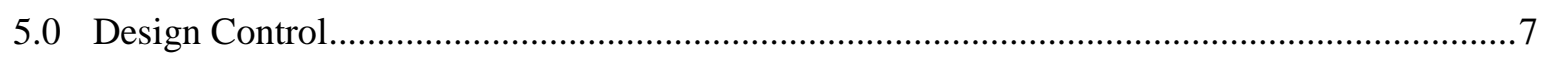

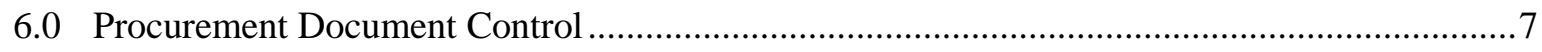

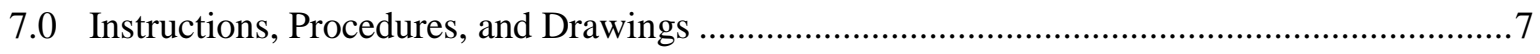

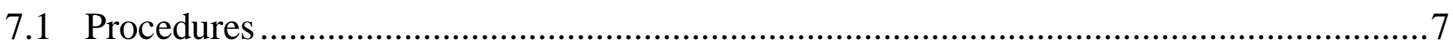

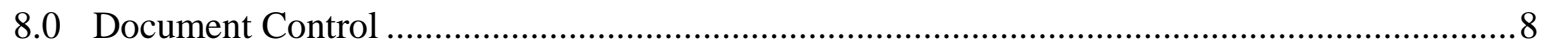

8.1 Procedures, Test Instructions, and Other Work Controlling Documents ..........................8

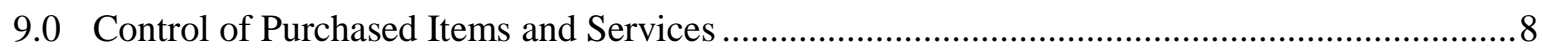

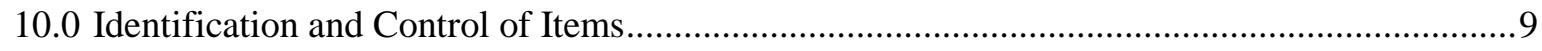

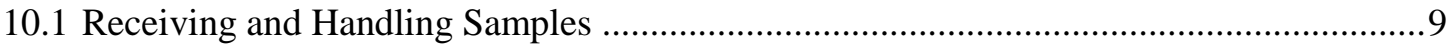

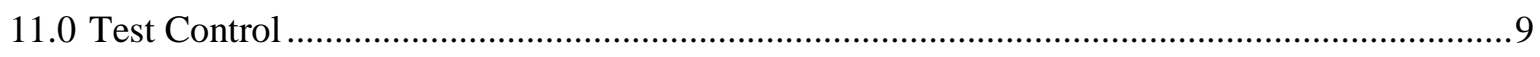

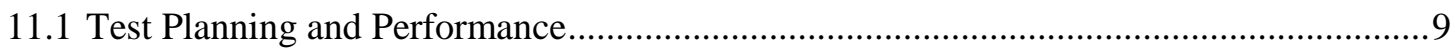

11.1.1 Developing the Test Plan .............................................................................

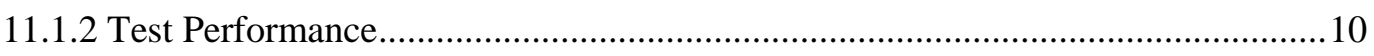

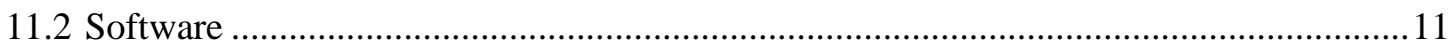

11.2.1 Software and Software Applications ............................................................. 11

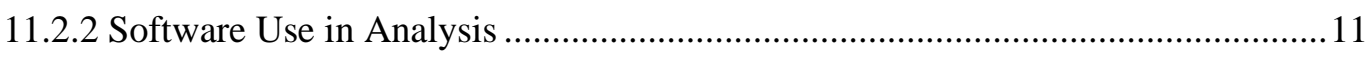

12.0 Control of Measuring and Test Equipment ................................................................... 11

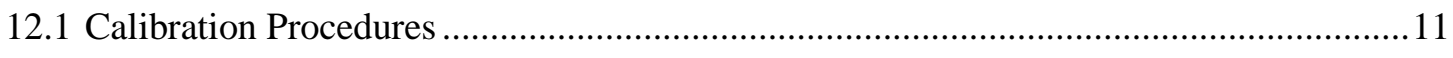

13.0 Control of Nonconforming Items and Corrective Action .................................................... 12

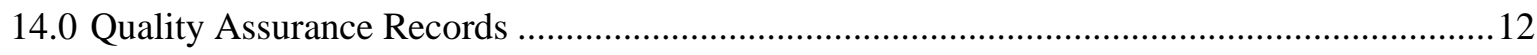




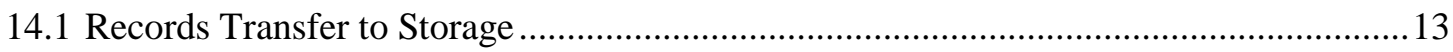

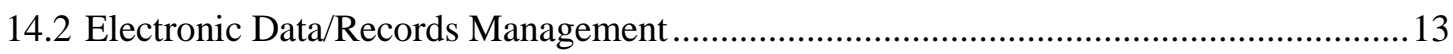

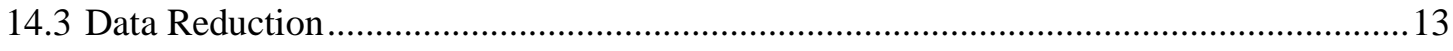

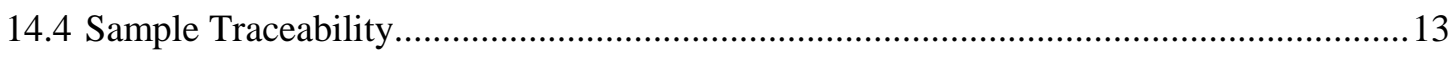

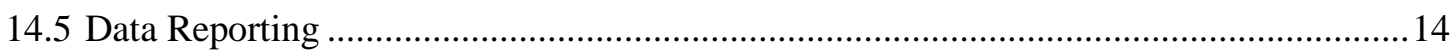

14.6 Laboratory Notebooks and Laboratory Record Books............................................... 14

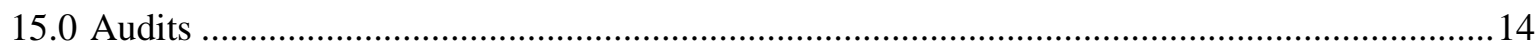

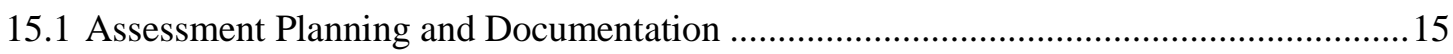

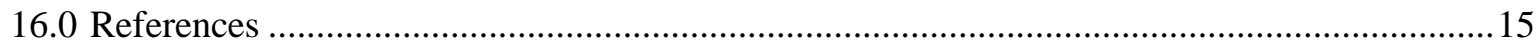

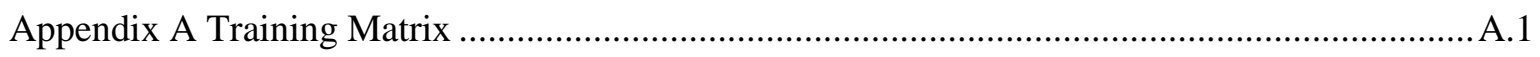

Appendix B Document Review and Approval Matrix............................................................ B. 1

\section{Tables}

1. NQA-1 Requirements Applicable to the Fuel Thermo-Physical Characterization Project............3 


\subsection{Introduction}

This quality assurance plan (QAP) provides the quality assurance requirements and processes that are applicable to the Fuel Thermo-Physical Characterization Project. The charter of the Fuel ThermoPhysical Characterization Project is to ready Pacific Northwest National Laboratory (PNNL) facilities and processes for the receipt of unirradiated and irradiated low enriched uranium (LEU) molybdenum (U-Mo) fuel element samples, and to perform analysis to support the Global Threat Reduction Initiative (GTRI) conversion program. PNNL's support for the program will include establishment of post-irradiation examination (PIE) processes, including thermo-physical properties, unique to the U.S. Department of Energy (DOE) laboratories These process will ultimately support submission of the base fuel qualification (BFQ) to the U.S. Nuclear Regulatory Commission (NRC) and revisions to HighPerformance Research Reactor (HPRR) Safety Analysis Reports (SARs) to enable conversion from highly enriched uranium (HEU) to LEU fuel. The project objectives are:

- Ready the 325 Building, the Radiochemical Processing Laboratory (RPL), for U-Mo sample receipt, segmentation, preparation and examination.

- Prepare a QAP to ensure data quality objectives are consistent with the applicable program standards.

- Ready sample preparation and examination processes that may affect BFQ, which include, but may not be limited to

- optical microscopy (OM)/ scanning electron microscopy (SEM) for determining post-irradiation fuel layer thicknesses

- laser flash analysis (LFA) to determine thermal diffusivity

- simultaneous thermal analysis/gravimetric thermal analysis (STA/GTA) including mass spectroscopy of fission gases

- pyncometry (density measurement) including weight and volume measurements

- determination of isotope conversion via analytical chemistry.

- Perform direct and indirect measurements of thermal and physical properties to support the development of a correlation (out of scope) of thermal properties as a function of uranium conversion within test reactors

- Perform other investigative (lower-risk) related examinations such as general SEM/OM and mechanical testing under basic PNNL How Do I? (HDI) controls. 


\subsection{Project Information}

\subsection{Title}

Global Threat Reduction Initiative Fuel Thermo-Physical Characterization Project

\subsection{Client}

U.S. Department of Energy, Office of Global Threat Reduction

\subsection{Authorizing Document}

The authorizing document is the Work Authorization Statement of Work, B\&R \#NN9002000. The work scope is managed under PNNL project number 62501.

\subsection{Quality Assurance Requirements}

The QAP is based on the requirements of the PNNL Quality Assurance Program, which is based on the American Society of Mechanical Engineers (ASME) NQA-1-2000. The plan also conforms to DOE Order 414.1C, Quality Assurance; and 10 Code of Federal Regulations (CFR) 830, Subpart A, Quality Assurance Requirements, as described in the PNNL standards-based management system known as HDI. The application of requirements is graded, using Subpart 4.2 of NQA-1-2000 to guide the process.

Project scope associated with measurement of thermal properties is subject to the Price Anderson Amendments Act (PAAA) as defined in the PNNL DOE Regulatory Compliance Program (DRCP) and implemented through HDI. The PNNL quality program has been approved by the DOE Pacific Northwest Site Office.

Table 1 outlines the NQA-1 requirements applicable to the Fuel Thermo-Physical Characterization Project. This table also identifies specific controls beyond those identified in HDI to enhance project management control based on identified risks, and meets client expectations as determined necessary by the project manager. 
Table 1. NQA-1 Requirements Applicable to the Fuel Thermo-Physical Characterization Project.

\begin{tabular}{|c|c|c|c|c|c|c|}
\hline NQA-1 Criteria & HDI & PEP/PMP & $\begin{array}{l}\text { Project Procedure } \\
\text { or Test Instruction }\end{array}$ & $\begin{array}{l}\text { Others Procedure } \\
\text { (ASO, SFO) }\end{array}$ & QA Plan & Comments \\
\hline $\begin{array}{l}\text { Organization } \\
\text { (NQA-1, Crit 1) }\end{array}$ & $\mathrm{X}$ & $\mathrm{X}$ & $\mathrm{X}$ & $\mathrm{X}$ & $\mathrm{X}$ & $\begin{array}{l}\text { HDI directs Laboratory-level R2A2s. R2A2s } \\
\text { are also identified for the project via project- } \\
\text { specific procedures and plans. Overall project } \\
\text { roles and responsibilities are in the PEP and } \\
\text { QAP. }\end{array}$ \\
\hline $\begin{array}{l}\text { QA Program } \\
\text { (NQA-1, Crit 2) }\end{array}$ & $\mathrm{X}$ & $\mathrm{X}$ & & & $\mathrm{X}$ & $\begin{array}{l}\text { HDI covers the base Laboratory QA program } \\
\text { requirements. Additional QA program } \\
\text { requirements are spelled out in the QAP and } \\
\text { PEP. }\end{array}$ \\
\hline $\begin{array}{l}\text { Includes: Indoctrination } \\
\text { \&Training }\end{array}$ & $\mathrm{X}$ & $\mathrm{X}$ & & $\mathrm{X}$ & $\mathrm{X}$ & $\begin{array}{l}\text { HDI covers the base Laboratory training } \\
\text { requirements. Additional training requirements } \\
\text { for the project are identified in this QAP, and } \\
\text { other endorsed procedures engaged for this } \\
\text { project. }\end{array}$ \\
\hline $\begin{array}{l}\text { Design Control } \\
\text { (NQA-1, Crit 3) }\end{array}$ & $\mathrm{X}$ & & & & $\mathrm{X}$ & $\begin{array}{l}\text { HDI covers the base Laboratory design } \\
\text { requirements for drawings of cell configuration } \\
\text { of equipment/layouts. Additional design } \\
\text { requirements are identified in the design section } \\
\text { of the QAP, Section } 5.0\end{array}$ \\
\hline $\begin{array}{l}\text { Procurement Doc Control } \\
\text { (NQA-1, Crit 4) }\end{array}$ & $\mathrm{X}$ & & & & $\mathrm{X}$ & $\begin{array}{l}\text { HDI covers the base Laboratory QA program } \\
\text { requirements. See QAP Section } 6.0 \text { for } \\
\text { additional procurement controls. }\end{array}$ \\
\hline $\begin{array}{l}\text { Instructions, Procedures \& } \\
\text { Drawings } \\
\text { (NQA-1, Crit 5) }\end{array}$ & $\mathrm{X}$ & & & $\mathrm{X}$ & $\mathrm{X}$ & $\begin{array}{l}\text { HDI covers the base Laboratory QA program } \\
\text { requirements for instruction, procedures, and } \\
\text { drawings. See QAP Section } 7.0 \text { for additional } \\
\text { controls. }\end{array}$ \\
\hline $\begin{array}{l}\text { Document Control } \\
\text { (NQA-1 Crit 6) }\end{array}$ & $\mathrm{X}$ & & & & $\mathrm{X}$ & $\begin{array}{l}\text { HDI covers the base Laboratory QA program } \\
\text { requirements for document control. See QAP } \\
\text { Section } 8.0 \text { for additional controls. }\end{array}$ \\
\hline
\end{tabular}


Table 1. (contd.)

\begin{tabular}{|c|c|c|c|c|c|}
\hline $\begin{array}{l}\text { Control of Purchased Items } \\
\text { and Services } \\
\text { (NQA-1, Crit 7) }\end{array}$ & $X$ & & & $X$ & $\begin{array}{l}\text { HDI covers the base Laboratory QA program } \\
\text { requirements for control of purchased items and } \\
\text { services. See QAP Section } 9.0 \text { for additional } \\
\text { controls. }\end{array}$ \\
\hline $\begin{array}{l}\text { Identification and Control } \\
\text { of Items } \\
\text { (NQA-1, Crit 8) }\end{array}$ & $X$ & & & $X$ & $\begin{array}{l}\text { HDI covers the base Laboratory QA program } \\
\text { requirements for identification and control of } \\
\text { items. See QAP Section } 10.0 \text { for additional } \\
\text { controls. }\end{array}$ \\
\hline $\begin{array}{l}\text { Test Control } \\
\text { (NQA-1, Crit 11) }\end{array}$ & $X$ & $X$ & & $X$ & $\begin{array}{l}\text { HDI covers the base Laboratory QA program } \\
\text { requirements for test control. See QAP Section } \\
11.0 \text { for additional controls. }\end{array}$ \\
\hline $\begin{array}{l}\text { Control of Measuring and } \\
\text { Test Equipment } \\
\text { (NQA-1 Crit 12) }\end{array}$ & $X$ & & $X$ & $X$ & $\begin{array}{l}\text { HDI covers the base Laboratory QA program } \\
\text { requirements for calibration control. See QAP } \\
\text { Section } 12.0 \text { for additional controls. }\end{array}$ \\
\hline $\begin{array}{l}\text { Control of Nonconforming } \\
\text { Items } \\
\text { NQA-1, Crit15 }\end{array}$ & $X$ & & & $X$ & $\begin{array}{l}\text { HDI covers the base Laboratory QA program } \\
\text { requirements for control of nonconforming } \\
\text { items. See QAP section } 13.0 \text { for additional } \\
\text { controls. }\end{array}$ \\
\hline $\begin{array}{l}\text { NQA-1, Crit16 } \\
\text { Corrective Action }\end{array}$ & $X$ & & & $X$ & $\begin{array}{l}\text { HDI covers the base Laboratory QA program } \\
\text { requirements for corrective action. See QAP } \\
\text { Section } 13.0 \text { for additional controls. } \\
\end{array}$ \\
\hline $\begin{array}{l}\text { Quality Assurance Records } \\
\text { (NQA-1, Crit 17) }\end{array}$ & $X$ & $X$ & $X$ & $X$ & $\begin{array}{l}\text { HDI covers the base Laboratory QA program } \\
\text { requirements for managing records. See QAP } \\
\text { Section } 14.0 \text { for additional controls. }\end{array}$ \\
\hline $\begin{array}{l}\text { Audits } \\
\text { (NQA-1, Crit 18) }\end{array}$ & $X$ & & & $X$ & $\begin{array}{l}\text { HDI covers the base Laboratory QA program } \\
\text { requirements for conducting assessments and } \\
\text { audits. See QAP Section } 15.0 \text { for additional } \\
\text { controls. }\end{array}$ \\
\hline
\end{tabular}

ASO = Analytical ServicesOperations

HDI $=$ How Do I?

$\mathrm{PEP}=$ project execution plan

$\mathrm{QA}=$ quality assurance

$\mathrm{QAP}=$ quality assurance plan

$\mathrm{R} 2 \mathrm{~A} 2=$ roles, responsibilities, accountabilities, and authorities

$\mathrm{SFO}=$ Shielded Facility Operations 


\subsection{Special Requirements or Specifications}

The client has not specified any special requirements or conditions at this time. Any other requirements prescribed by the project manager are outlined in this QAP and other project work controlling documents (e.g., the project management plan [PMP]).

\subsection{Project Scope}

PNNL will assist GTRI with out-of-pile characterization of LEU-Mo fuel using capabilities and experience base, particularly in RPL and 3410. In some cases, the capabilities and experience base are unique to PNNL, and in other cases will reduce pressure on other programmatic areas by taking advantage of similar/redundant characterization capability at PNNL. In either case, the LEU-Mo Out-ofPile Characterization for the Global Threat Reduction Program scope offers a risk mitigation strategy to the GTRI customer.

\subsection{Change Control (Scope, Schedule, Budget)}

The project scope, schedule, and budget baseline are documented, tracked, and reported as outlined in the PMP and project execution plan (PEP).

\subsection{Project Organization and Responsibilities}

See the PEP for project-specific organizational structure, roles, and responsibilities.

\subsection{Quality Program}

\subsection{Quality Program Description}

The Laboratory quality requirements are communicated to staff through HDI, which is a standardsbased management system for managing the delivery of Laboratory-level policies, requirements, and

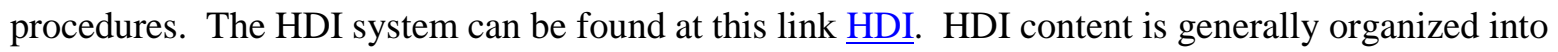
work controls and workflows that address specific topics. As determined necessary by the project manager, additional implementation documents (e.g., procedures or instructions) will be provided to Laboratory staff assigned to the project.

An essential element of the quality program includes a graded approach to implementing the program based upon value, risk, customer focus, and flexibility, so that individual customer needs and expectations can be met effectively and efficiently at the program and project levels. When required, the quality of work performed is verified by person(s) or organizations that are not directly responsible for performing the work. 


\subsection{Training}

Staff performing activities affecting quality of the project shall be issued documented training assignments including applicable project administrative and technical procedures. Additionally, staff will be trained to the PEP and QAP. See the training matrix in Appendix A. Additional training needs will be addressed as follows:

- The project manager and task managers will evaluate project-specific training needs. Training assignments will be issued as determined necessary by the project manager and task managers.

- Research staff who perform analytical work, or are involved in the interpretation of results/data will be approved/authorized to work on the project.

- The project manager will assign reading and/or briefing of procedures as needed. If training is assessed and the need for formalized training is identified, the staff member will be scheduled to attend a formal training class.

- Training may be documented on a briefing document, a Group Reading Assignment Form, an Individual Reading Assignment Form, or a Training Attendance Sheet. These forms are available in HDI at the HDI workflow, "Identify, Schedule and Complete Training." Documentation shall be sent to the PNNL Laboratory Training Coordinator for input into the training database. The training database will contain the record copy of project staff training.

- Resumes of key project technical staff will be retained on file in the project records.

Project staff shall comprise personnel who are knowledgeable and possess adequate skills to perform all assigned tasks. The project manager will identify any additional specific project-related processes that require project-staff training and qualification, and identify who is responsible for making sure the project-specific training is developed and delivered, and manage changes in accordance with the HDI workflow, "Identify, Schedule and Complete Training."

The project manager or training coordinator shall confirm that training has been completed prior to project staff conducting work that requires the training. The project manager or delegate shall also make sure that project-required training (and retraining for changes) records are maintained in accordance with the HDI workflow "Identify, Schedule and Complete Training" and the project file plan. 


\subsection{Design Control}

Design activities for modifications to the RPL facility to accommodate research equipment in the hot cells are conducted in accordance with ADM-CM-058, Facility Design Manual. Engineering design plans will be prepared and approved to control the design activities.

The research tasks performed under the control of this QAP are considered scientific investigations and provide no design deliverables, and therefore do not involve the preparation of design drawings or require the use of a formal design controls.

\subsection{Procurement Document Control}

Procurement of equipment, materials, and services are performed as specified in the HDI "Acquire Product or Service" workflow. This workflow identifies that measures are established to control procurement activities of material, equipment, and services from planning through receipt. These systems provide the processes to ensure that items and services meet established requirements and perform as specified. In addition, these systems also specify requirements regarding the evaluation and selection of suppliers. When possible, suppliers listed on the PNNL Evaluated Suppliers Listing or other accredited listings (located in HDI) should be used for the procurement of items and services that affect quality.

Procurement requirements shall be stated in applicable procurement documents. A graded approach shall be used to define quality assurance, technical, and other requirements for the subcontractor/supplier.

When QA requirements are needed or when the project manager (as the technical administrator for the project) determines necessary, the quality engineer is engaged to work with staff to develop the appropriate clauses and approach to the procurement. The quality engineer will review the requisitions.

\subsection{Instructions, Procedures, and Drawings}

\subsection{Procedures}

Procedures, instructions and similar work-controlling documents used by the project are prepared, developed, and approved in accordance with the HDI subject area, "Procedures, Permits, and Other Work Instructions." This work flow includes minimum procedure content requirements. In addition, any procedures that are developed for use in the RPL require processing through the RPL Independent Review Committee (IRC). See Appendix B for additional approval requirements.

The Fuel Thermo-Physical Characterization Project will use a combination of HDI, project-specific, and existing organizational procedures to implement the quality program for the project. The project manager will approve any project-specific procedures and endorse existing organizational procedures to be used on the Fuel Thermo-Physical Characterization Project. A separate project procedure list is maintained to record the project procedures as they are developed, vetted, and approved. 


\subsection{Document Control}

\subsection{Procedures, Test Instructions, and Other Work Controlling Documents}

Technical or administrative procedures referenced by this QAP, or listed on the project procedure list and used by PNNL staff are approved, distributed, and controlled in accordance with the HDI workflow, "Manage Controlled Documents" and as defined in the Document Review and Approval Matrix (in Appendix B). The approved official copy of project procedures will be maintained on the project SharePoint site, accessible to all project staff for use. If staff members use a printed copy of a procedure, they are expected to check the SharePoint site to make sure they printed the latest version of the procedure.

Test plans and other test instructions used by PNNL staff shall be developed, approved, and controlled to ensure consistent application by those staff performing the defined task(s). These test plans/instructions shall be developed, approved, and controlled per Appendix B. Modifications to any of the internal procedures shall be made either by revision or issuance of an interim change notice (ICN). At a minimum, ICNs must be approved by the project manager.

In the event the owning organization revises a technical procedure the project has endorsed for use, the project will use the version identified on the project procedure list until the revision has been approved for use by the project manager.

Procedures and other work controlling documents are required to be reviewed at least every two years.

\subsection{Control of Purchased Items and Services}

To ensure that procured items and services satisfy the technical and quality requirements of the user and/or client, all procurements shall be evaluated for acceptability by the technical administrator/staff member in accordance with the applicable HDI work flow, "Receive and Inspect Product or Service."

A quality assurance (QA) representative shall approve procurements containing QA requirements. Procurement documents shall specify technical and QA requirements, including documentation to be furnished by the supplier, when necessary.

Depending on the risk, complexity, and importance of the item or service being obtained, controls are necessary to determine the suppliers' capabilities to meet requirements and/or deliver items and services to specifications. These controls may consist of source evaluations and selections, evaluation of the items/services delivered by objective evidence, review of documentation provided, source inspections during supplier activities, audit, or receipt inspection upon delivery of the item or service. The method to accept the items and services procured are determined when the purchase is being established through the purchase requisition, contract, or other acquisition method. See HDI workflow "Acquire Product or Service." 
Submittals from suppliers shall be reviewed to verify their compliance with the procurement document technical and QA requirements. This review is performed by an Acquisition Quality Support Service (AQSS) subject matter expert (SME).

At a minimum project staff members shall verify that items and services requested are acceptable when received in accordance with HDI requirements "Receive and Inspect Product or Service."

\subsection{Identification and Control of Items}

\subsection{Receiving and Handling Samples}

Direction for sample handling and storage is provided in HDI, "Manage Sample" workflow. Radiological samples are managed according to the "Radiological-General" work control of HDI. All radiological materials are tracked using the "Radioactive Material Tracking" system. Basic sample receiving, handling and identification requirements must meet this workflow and the project sample identification procedure, \#62501- Sample Nomenclature.

Sample traceability is to be maintained from the original samples received to the point of testing/analytical result outputs and or test reports. Documentation of sample and subsample identifications are maintained from the original samples received from a client.

\subsection{Test Control}

\subsection{Test Planning and Performance}

Test plans are used to document a single or related set of experiments or tests.

\subsubsection{Developing the Test Plan}

The test plan shall contain the following information:

- a title and/or number including date or revision

- dated signatures of the preparer, technical lead, project manager or task manager. Consider obtaining other SME approvals depending on scope of the test plan, (e.g., Safety, Quality, Security, Radiological).

The content of each test plan will depend on the scope of the analysis or test. The following is a brief description of mandatory and optional items to be considered in the preparation of the test plan:

- Purpose/Description (mandatory) - Provide a short narrative on the purpose of the experiment/test/activity.

- Prerequisites (optional) - List items, conditions, or other concerns that must be satisfied prior to beginning the test. 
Example: Prior to beginning the work activity, the staff must complete special training on other plans or procedures that will be used in conjunction with the test plan, special handling or storage requirements, special access or permits, and required records that need to be generated as the result of the work activity.

- Safety (mandatory) - Describe the hazards associated with the work such as physical agents (e.g., temperature, pressure, noise, electrical), hazardous environments (e.g., confined spaces, remote locations, heat/cold stress), and hazardous materials (e.g., flammables, corrosives, highly toxic chemicals, carcinogens). Describe the methods used to mitigate the hazards that were identified (e.g., personal protective equipment, time periods away from the hazard, alarms, location of nearest aid station).

- Materials and Equipment (optional) - List the materials and equipment necessary to complete the work.

- Measuring and Test Equipment (mandatory) - List the equipment that will be used to make the measurements; include the calibration requirements, system checks, and quality control checks in this section or in the work instructions section of the test plan.

- Pretest Verification (mandatory) - Determine if certain items of a test require verification prior to their use and indicate how the verification will be done.

- Documentation, Records and Reporting (mandatory) - Describe the records and documentation required, where the data collected during the test should be documented (e.g., lab/data forms, laboratory record books [LRBs], entered into a computer, downloaded from computer to hardcopy). Additionally, describe what will be reported, to whom, and due date(s) if known. Include test acceptance criteria or expected ranges as appropriate to determine what constitutes success.

- Work Instructions (mandatory) - Provide step-by-step instructions and/or non-sequential instructions and/or reference test procedures that will contain the work instructions (whichever is more appropriate to the activity). Each step or instruction shall be as simple as possible but with sufficient detail so that individuals experienced in the technology or activity involved can easily understand. The following types of information should be considered for inclusion: administrative-control hold points (i.e., where safety, quality, radiological, or other approvals or actions are required before proceeding); cautions that indicate potentially hazardous situations which, if not avoided, may result in death, injury, or damage to facilities or equipment; and notes that call attention to supplemental information that assists the user in making decisions or improving work performance.

\subsubsection{Test Performance}

Tests are performed in accordance with the test plan and or test instructions. The task lead is responsible for making sure that the current version is used to perform the work.

If changes to the test plan are required during the execution of the work, the task lead shall approve the changes and document the deviation and the justification or rationale for the change. 


\subsection{Software}

\subsubsection{Software and Software Applications}

Software is defined as computer programs - including computer programs embedded in firmware. Software is excluded if it is an integral part of firmware or equipment, where all software maintenance is performed by the vendor and the software is verified as an integral part of the system (e.g., calibration with known standard materials).

All software applications used for the projects shall be graded according to the HDI workflow "Roadmap for Projects."

\subsubsection{Software Use in Analysis}

The project will conduct work in accordance with requirements for the control of software used in analyses as defined in the HDI workflow "Roadmap for Projects." Included is the use of software of any kind to conduct analyses delivered, or in support of a deliverable to the customer including data analysis tools such as spreadsheets and statistical analysis software, databases, and modeling and simulation tools. Excluded are software productivity tools such as word processors and spreadsheets when no automated calculations, macros, or scripts are used.

Spreadsheets are to be checked to makes sure that they perform their functions for the task correctly. The verification is to be documented on the spreadsheet or by a separate worksheet. The verification can be included as a tab in the file (such as in Excel).

\subsection{Control of Measuring and Test Equipment}

\subsection{Calibration Procedures}

Measuring and test equipment (M\&TE) used by project staff to collect quality-affecting data that are calibrated by the user (Category $2 \mathrm{M} \& \mathrm{TE}$ ) or by an approved external or internal source (Category 1 M\&TE). Calibration is performed in accordance with the HDI subject area, "Calibrate Equipment for Use."

The method of user calibration is to be documented. This can be done by including the user calibration requirements in the technical procedure or preparing a separate procedure.

Upon receiving calibrated equipment, staff members must review the documentation for acceptability, verify the proper operation of the M\&TE, and check the calibration label to make sure it is within due dates and is appropriate for the type of work.

The M\&TE shall be controlled as described in accordance with the HDI workflow "Calibrate Equipment for Use." Externally calibrated M\&TE, such as balances, are calibrated in accordance with manufacturer's tolerances unless other control limits are specified and justification is provided. 
Data sheets and log book entries are used to document performance checks. Calibration reports, calibration data, and procedures are maintained as project records.

\subsection{Control of Nonconforming Items and Corrective Action}

Items or processes that do not conform to specified requirements are to be controlled to prevent inadvertent installation or use. These controls provide for identification, documentation, evaluation, segregation when practical, and disposition of nonconforming items.

Conditions adverse to quality are to be identified promptly and corrected as soon as practicable. In the case of significant conditions adverse to quality, the cause of the condition shall be determined and corrective action taken to preclude recurrence. The identification, cause, and corrective action for significant conditions adverse to quality shall be documented and reported to appropriate levels of management. As necessary, completion of corrective actions is to be verified.

Project staff members are to follow HDI workflow "Roadmap for Projects" and specifically the "Issue Discovered" step in the "Conduct Critique and Cause Analysis" workflow. Issues (nonconformance) are documented using the Issue Tracking Tool (ITS). If project staff members have trouble determining if they have an issue (nonconformance) and what corrective actions are necessary, they should contact the project quality engineer for assistance.

If immediate corrective action is required, the quality problem will be directly entered into the ITS, and actions will be taken as necessary.

\subsection{Quality Assurance Records}

The HDI definitions of project records and record material apply to this project. As stated in the HDI workflow, "Manage Project Records," project records are any recorded information relating to a specific project. Record material includes information, regardless of its media (e.g., hard copy, electronic, or microfilm), created or received in connection with Pacific Northwest Division business or research activities that documents research and administrative functions, policies, decisions, procedures, operations, or other activities, and is preserved for its value.

NOTE: E-mail that is record material must be printed and maintained as the record copy unless the e-mail is put directly into the project TRIM file.

Record material that is not stored in notebooks or LRBs or is not electronic data gathered from instruments and/or laboratory equipment, such as project-specific data forms, shall be scanned and managed as portable document format (PDF) files. The record material shall be scanned and archived quarterly or more often if the accumulation of records is significant and inadvertent damage or loss would affect or damage the project.

Project records are legible, identifiable, and maintained in accordance with the PNNL HDI workflow, "File and Maintain Project Records." Test results documented in LRBs are reviewed semiannually by a technically qualified individual who did not perform the work. The reviewer will verify there is sufficient 
detail to retrace the investigation and confirm the results. LRBs are managed according to HDI workflow "Use Laboratory Record Book."

The project manager, delegate, or project records custodian prepares and submits a File Plan for review and approval by the Records Management representative and the project manager. The File Plan is updated annually at a minimum, or when a major change to the program occurs.

\subsection{Records Transfer to Storage}

On a periodic basis (six months from the start of the project in FY 2012, then monthly after that), the records custodian will transfer to storage inactive hard copy records as identified by the project staff as not required for day-to-day operations. Some project records and special project correspondences may be maintained by the project until the completion of the activity or project. The project records custodian generates the appropriate records transfer form per HDI workflow, "File and Maintain Project Records."

Within 90 days of project completion or termination of the project, records shall be transferred to storage and/or the client. The project records custodian completes the appropriate internal forms.

\subsection{Electronic Data/Records Management}

Electronic data gathered from project work execution and/or instruments in the laboratory are maintained and managed appropriately to allow for reproducible results. Electronic data that are directly delivered or used in analysis, or are delivered to the client, are maintained as project records in accordance with the requirements of the HDI workflow "File and Maintain Project Records."

\subsection{Data Reduction}

Data measured during project investigations are compiled, evaluated, and documented as described in the following paragraphs. Samples and associated analyses are tracked to assure successful sample collection and traceability.

Verification of analytical data is performed, as appropriate to verify the reliability and validity of laboratory measurements based on accuracy, precision, and detection limits. Representativeness, completeness, and comparability may also be evaluated for overall quality. These parameters are evaluated through laboratory quality control (QC) checks, replicate sampling and analyses, analysis of standards, blind standards and blanks, and/or interlaboratory comparison or as identified in test plans. When parameters are outside acceptance criteria, corrective actions are taken to prevent a future occurrence and any affected data are appropriately identified.

\subsection{Sample Traceability}

Raw data, sampling metadata, and instrument calibrations shall be stored to allow an auditable, reproducible link between samples and finalized data. 


\subsection{Data Reporting}

All data reported shall be traceable to the M\&TE and procedure (including procedure revision) or test plan used, and if the reported results are quantitative, a valid calibration. The analyst shall sign or initial and date the data reports unless the results printed by the instrument include identification of the analyst and date. A staff member other than the person who performed the work, and who is knowledgeable in the area being reviewed, shall review the data before results are reported. When the data review identifies suspect data, those data are investigated to establish whether they reflect true conditions or an error. Interpretative data, test results, and reports are released through the information release process in accordance with the HDI workflow, "Review and Approve Information Product."

\subsection{Laboratory Notebooks and Laboratory Record Books}

Laboratory notebooks and/or LRBs used by the project staff shall be managed, controlled, and reviewed in accordance with the HDI workflow "Manage Laboratory Record Book." In particular, the project manager shall ensure that all LRBs are reviewed at least twice per year. The reviewer, a qualified individual, confirms that there is sufficient detail to trace the investigation and confirm the test results or repeat the investigation and achieve comparable results, without recourse to the original investigator.

Specific LRB requirements are identified in HDI workflow Exhibit, "Procedure for the Use of Unclassified Laboratory Record Book."

\subsection{Audits}

Audits and assessments are performed to measure the effectiveness of the quality systems and processes implemented by the project. The following types of assessments may be used at varying frequencies during the lifecycle of the project:

- Management self-assessment - An assessment performed by those immediately responsible for overseeing and/or performing the work to establish whether policies, practices, and procedures are adequate for assuring results needed.

- Management independent assessment - An assessment performed by an individual or group independent of the work performed to make sure that policies, practices, and procedures are adequate for assuring results needed.

- Technical/Independent assessment - An assessment performed by an individual or group technically competent to perform the work but independent of the work being performed to make sure qualitative and quantitative aspects of the work are accomplished according to documented specifications.

If the complexity and/or significance of the work performed warrants it, the project manager will direct the Quality representative and/or another staff member to conduct an additional assessment. The assessment is documented and retained in the project records. Documentation of the above assessments, as well as any external assessments performed is maintained as project records. 


\subsection{Assessment Planning and Documentation}

The project management team (including the project manager, task leads, and appropriate project staff) plan assessments in consultation with the project quality engineer. An audit/assessment schedule is developed by the project quality engineer with project manager approval. Assessments may be performed by the project staff, project management, and/or the quality engineer in accordance with the HDI workflow, "Conduct Internal Assessment or Audit." The assessor plans the assessment on a SelfAssessment Planning Form where the scope of the assessment, topic, and supporting references are documented in the plan. The project manager (or delegate) approves the plan.

Results of audits/assessments will be documented and entered into ITS. The corrective action and action owner will be documented in ITS. The action owners are assigned by the project manager (or delegate). The project quality engineer will monitor completion of corrective actions and close the condition after verifying completion of corrective actions. The assessment report is distributed to the appropriate staff, project manager, and project records.

\subsection{References}

10 CFR 830. 2012. Subpart A- "Quality Assurance Requirements." U.S. Code of Federal Regulations, U.S. Department of Energy, Washington D.C.

42 USC . 2011. Price Anderson Amendment Act of 1988. Public Law 100-48, 1988, as amended.

ADM-CM-058, Rev. 5. Year. Facility Modification Manual. Pacific Northwest National Laboratory, Richland Washington.

ASME NQA-1-2000. Quality Assurance Requirements for Nuclear Facility Applications. The American Society of Mechanical Engineers, New York, New York.

DOE Order 414.1C. 2011. "Quality Assurance.” U.S. Department of Energy, Washington D.C. 



\section{Appendix A}

Training Matrix 



\section{Appendix A}

\section{Training Matrix}

This table provides an example of the training matrix that will be maintained as part of this program. The content of the training matrix may be modified by the project manager to fit the needs of the project.

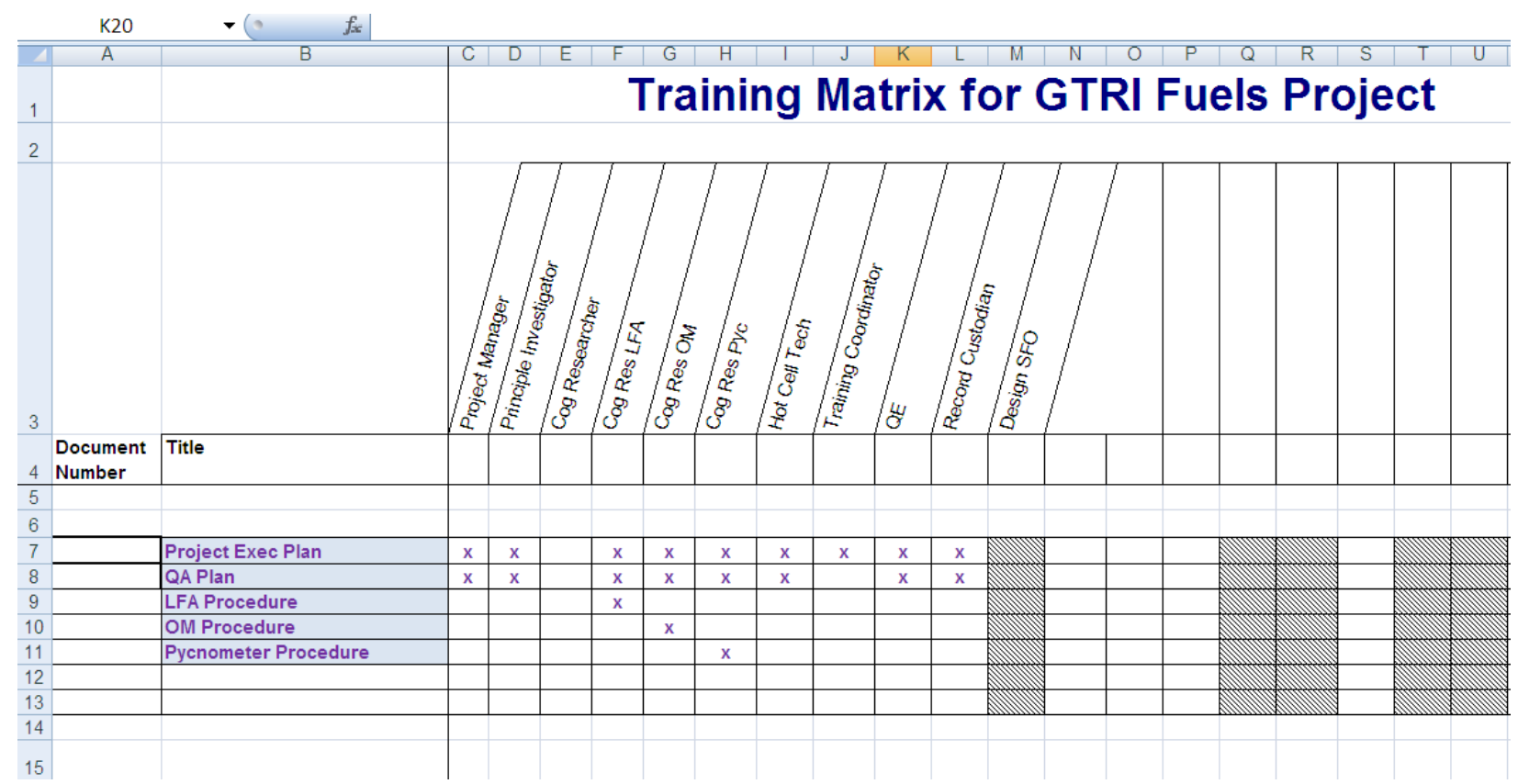





\section{Appendix B}

\section{Document Review and Approval Matrix}





\section{Appendix B}

\section{Document Review and Approval Matrix}

This table lists the minimum procedure approval requirements for controlled documents within this project. Additional approvals may be required by the project manager.

\begin{tabular}{|l|c|c|c|c|c|c|c|c|c|l|}
\hline $\begin{array}{l}\text { Document } \\
\text { Type }\end{array}$ & Preparer & $\begin{array}{l}\text { Independent } \\
\text { Reviewer }\end{array}$ & PI & PM & QE & PMOD & Editor & ADC & ERICA & Comments \\
\hline PEP & $\mathrm{X}$ & & & $\mathrm{X}$ & & $\mathrm{X}$ & & & & \\
\hline QAP & $\mathrm{X}$ & & & $\mathrm{X}$ & $\mathrm{X}$ & $\mathrm{X}$ & & & & \\
\hline $\begin{array}{l}\text { Procedure- } \\
\text { Project }\end{array}$ & $\mathrm{X}$ & $\mathrm{X}$ & $\mathrm{X}$ & $\mathrm{X}$ & $\mathrm{X}$ & & & & & \\
\hline $\begin{array}{l}\text { In addition, RPL } \\
\text { procedures } \\
\text { require } \\
\text { processing per } \\
\text { RPL-PLN-700 }\end{array}$ \\
\hline $\begin{array}{l}\text { Procedure- } \\
\text { Other } \\
\text { Organizational }\end{array}$
\end{tabular}

$\mathrm{ADC}=$ authorized derivative classifier

ERICA = Electronic Records and Information Capture Architecture

GTRI $=$ Global Threat Reduction Initiative

$\mathrm{PEP}=$ project execution plan

$\mathrm{PM}=$ project manager

PMOD = project management office director

$\mathrm{QAP}=$ quality assurance plan

$\mathrm{QE}=$ quality engineer

$\mathrm{RPL}=$ Radiochemical Processing Laboratory 


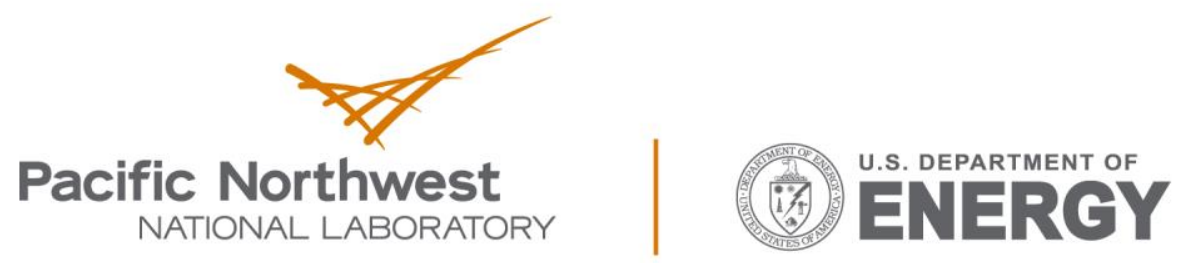

Proudly Operated by Battelle Since 1965

902 Battelle Boulevard

P.O. Box 999

Richland, WA 99352

1-888-375-PNNL (7665)

www.pnnl.gov 